\title{
Implementation of the Problem Base Learning Model combined with E-STEM Based Student Worksheets on Learning Outcomes and Self Efficacy on Environmental Pollution Materials
}

\author{
Cut Putri Amalya ${ }^{1}$, Wiwit Artika1,2*, Safrida ${ }^{1}$, Cut Nurmaliah' ${ }^{1}$, Muhibbuddinn ${ }^{1}$, M. Syukri2,3 \\ ${ }^{1}$ Master of Biology Education Faculty of Teacher Training and Education, Syiah Kuala University, Banda Aceh, Indonesia \\ ${ }^{2}$ STEM Research Centers at Syiah Kuala University in Banda Aceh, Indonesia \\ ${ }^{3}$ Faculty of Teacher Training and Physics Education, Syiah Kuala University, Banda Aceh, Indonesia
}

DOI: $\underline{10.29303 / \text { ippipa.v7iSpecialIssue.962 }}$

\section{Article Info}

Received: September $14^{\text {th }}, 2021$

Revised: October 31st, 2021

Accepted: November 6 $6^{\text {th }}, 2021$

\begin{abstract}
The learning process has not emphasized the development of skills; this is because in learning students tend to memorize concepts so that learning outcomes and selfefficacy are not trained optimally. The formulation of the problem in this study is: is there a difference in learning outcomes and student self-efficacy between the use of the Problem Base Learning model combined with the E-STEM-based Student Worksheet with the Problem Base Learning model on environmental pollution material at MAN Banda Aceh? This research is quantitative with an experimental research approach. The research design used was pretest-posttest control group design. The population of this study was all students of class X MAN 3 Banda Aceh, totaling 84. The sampling technique used a total sampling of 84 students. The instrument used to measure learning outcomes is multiple choice questions using 30 questions and self-efficacy is measured using a questionnaire. Data analysis of learning outcomes and self-efficacy of students using independent sample $\mathrm{t}$-test at a significant level of 0.05 . The results showed that there were differences in student learning outcomes and self-efficacy after applying the Problem Base Learning model combined with the E-STEM-based Student Worksheet on environmental pollution materials at MAN Banda Aceh.
\end{abstract}

Keywords: Student Worksheets Based on E-STEM; Problem Based Learning; Learning Outcomes; Self-Efficacy

Citation: $\quad$ Amalya, C. P., Artika, W., Safrida, S., Nurmaliah, C., Muhibbuddin, M., \& Syukri, M. (2021).Implementation of the Problem Base Learning Model combined with E-STEM Based Student Worksheets on Learning Outcomes and Self Efficacy on Environmental Pollution Materials. Jurnal Penelitian Pendidikan IPA, 7(SpecialIssue), 37-38. https://doi.org/10.29303/jppipa.v7iSpeciallssue.962

\section{Introduction}

Learning is generally defined as a change in an individual through experience, and not because of the growth or development of his body or the characteristics of a person from birth that learning and development are closely related. The learning process occurs intentionally or unintentionally and lasts all the time and leads to a change in the learner. The change in question is a permanent change in behavior in the form of knowledge, understanding, abilities, and new habits acquired by individuals (Trianto, 2009).

Learning outcomes can be interpreted as the maximum results that have been achieved by a student after experiencing the teaching and learning process in studying certain subject matter. Learning outcomes are not absolute in the form of values, but can be in the form of changes, reasoning, discipline, skills and so on that lead to positive changes (Hamalik, 2007). 
Learning innovation is needed to change learning that is solely teacher-centered into learning that activates students. Learning innovation can be done by choosing an innovative and effective and appropriate learning model to improve learning outcomes and self-efficacy. Self-efficacy is a selfassessment in the form of an individual's subjective belief about his or her ability to carry out tasks and in overcoming problems or obstacles that occur, as well as taking the necessary actions to achieve optimal results or an expected goal. Indicators of self-efficacy are level, generality, and strength (Hendriana et al, 2018).

Students' self-efficacy can be seen by applying the Problem Based Learning Model which is active learning and is very effective in creating knowledge, and can improve analysis, evaluation and creation skills (Apriyani, 2019).

Problem Based Learning model is an active learning and very effective in creating knowledge, and can improve the ability of analysis, evaluation and creation (Barrows, 2002). Problem Base Learning combined with STEM education is used as a learning strategy to produce meaningful learning through the systematic integration of knowledge, concepts, and skills (Utomo, 2014).

Previous research on the use of Problem Base Learning based on E-STEM has never been done, so the researchers tried to do research using Problem Base Learning based on E-STEM. The development of ESTEM started from the STEM approach through changes in global issues that have been developed on an environmental basis or known as Environmental STEM (E-STEM).

E-STEM is a learning process that enables individuals to explore environmental problems, engage in problem solving, and take action to improve the environment and increase knowledge and awareness about the environment and its associated challenges commitment to making informed decisions and taking responsible action (NAAEE, 2013).

The E-STEM approach offers an opportunity to emphasize explicitly the mutualistic relationship between EE (Environmental Education) and SE (Science Education) by advancing learning outcomes important to both. It does so by using the environment as a physical context, a conceptual topic, or both, to stimulate knowledge about natural systems, while developing problem solvers equipped to address environmental challenges (Gupta et al., 2018).

According to the United States (2018) the components of environmental education are: (1) Awareness and sensitivity to the environment and environmental challenges; (2) Knowledge and understanding of the environment and environmental challenges; (3) Attitude to care for the environment and motivation to improve or maintain environmental quality; (4) Skills to identify and help solve environmental challenges; (5) Participation in activities that lead to the resolution of environmental challenges.

The results of interviews with biology teachers, observations and findings on the teaching and learning process at MAN Banda Aceh found that the learning process did not emphasize skill development, this was because in learning students tended to memorize the concepts given by the teacher without being balanced with the ability to apply the concepts that were taught. found both in the surrounding environment, so that learning outcomes are low and self-efficacy is not trained. In addition, the learning process at MAN 3 Banda Aceh has not used indicators that refer to skills development so that learning outcomes are not optimal.

Based on school data, the score of the Minimum Completeness Criteria for students at MAN 3 Banda Aceh in class X-IPA that has not been completed is 52 students or $69.33 \%$. This shows that students who have not reached the Minimum Completeness Criteria are more than half the number of students in a class. In addition, the application of the Problem base learning model based on the E-STEM Student Worksheet is also not widely used.

The characteristics of the System-based Student Worksheet used in this study are: (1) The environmental stage allows individuals to explore environmental problems and take action to solve environmental problems by assembling tools to protect the environment; (2) Science as a process carried out in assembling tools to protect the environment; (3) Technology as an application or tool used in assembling tools to protect the environment; (4) Engineering as engineering in assembling tools to protect the environment; (5) Mathematics as a mathematical concept used to assemble tools to protect the environment.

\section{Method}

This research was conducted at MAN 3 Banda Aceh. The time of the research was carried out in the even semester of the 2021/2022 academic year in class $X$ MAN 3 Banda Aceh. The research approach uses quantitative, while this type of research is applied research, the research conducted measuring learning outcomes and self-efficacy.

This study uses a quasi-experimental method is a research method carried out to determine the consequences that arise from a treatment that is given intentionally. The design used is the pretest-posttest control group design, which is presented in the table below. 
Table 1. Pretest-Posttest Control Group Design

\begin{tabular}{lccc}
\hline Groups & Pretest & Treatment & Posttest \\
\hline A (treatment) & $\mathrm{O}_{1}$ & $\mathrm{X}_{1}$ & $\mathrm{O}_{2}$ \\
B (Control) & $\mathrm{O}_{1}$ & $\mathrm{X}_{2}$ & $\mathrm{O}_{2}$ \\
\hline
\end{tabular}

Information:

$\mathrm{X}_{1}$ : Using Problem Base Learning combined with

Student Worksheets E-STEM based

$\mathrm{X}_{2}$ : Using the Problem Base Learning model

$\mathrm{O}_{1}$ : Pretest score

$\mathrm{O}_{2}$ : Posttest score

The population in this study were all students of class X IPA MAN 3 Banda Aceh with a total of 84 students. The parameters measured in this study are: learning outcomes and self-efficacy.

The instrument used is

\section{Measuring Learning Outcomes}

To measure learning outcomes using multiple choice tests by adopting Karlina's et al., (2021) learning outcomes questions. Each item that is answered correctly is given a score of 1 , while those who do not answer the question incorrectly or do not answer the question are given a score of 0 . The number of scores obtained by students will be analyzed to obtain the value of learning outcomes using the equation according to Arikunto (2009) as follows.

$$
p=\frac{\text { Total Score Acquisition }}{\text { Total Score }} \times 100 \%
$$

After obtaining the value of learning outcomes, then the independent sample t-test was carried out, namely the normality test and homogeneity test. If the data is normally distributed and homogeneous, then the parametric test is used, namely the independent sample t-test. Meanwhile, if the data is not normally distributed and not homogeneous, then a nonparametric test is used, namely the Mann Whitney test. The normality test used is Kolmogorov Smirnov, with the criteria if $p>0.05$, then the distribution is normal. Homogeneity test using Levene test, with criteria if $p>0.05$, then homogeneous. Data were analyzed using SPSS version 21 .

\section{Measuring Self Efficacy}

Students' self-efficacy is measured using nontest, namely a questionnaire in the form of pre-test and post-test questions. Questionnaires were given as many as 30 questionnaires. Students express how much they agree or disagree with the statement by choosing responses from strongly agree (5), agree (4), either agree or disagree (3), disagree (2) and strongly disagree (1) (Güneş, 2018).
The self-efficacy questionnaire used adopts the questionnaire developed by Hairida (2017) which consists of three aspects, namely 1) level, relating to the degree of difficulty of the task at hand. A person's acceptance and belief in a task is different, maybe people are only limited to simple, medium or difficult tasks. Perceptions of each individual will be different in looking at the level of difficulty of a task, 2) generality, is a feeling of ability shown by individuals in different task contexts, both through behavior, cognitive and affective, and 3) strength, the number of scores obtained obtained from the self-efficacy of students, then searched by percentage and categorized according to the criteria for the percentage score of the questionnaire. How to calculate the percentage as follows.

$$
p=\frac{\text { Total Score Acquisition }}{\text { Total Score }} x 100 \%
$$

The percentage value of self-efficacy obtained from the calculation is then categorized according to Table 2.

Table 2. Self-Efficacy Category Guidelines

\begin{tabular}{lll}
\hline No & Value Interval $(\%)$ & Category \\
\hline 1 & $(85 \leq \mathrm{p} \leq 100)$ & Highest \\
2 & $(70 \leq \mathrm{p}<85)$ & High \\
3 & $(55 \leq \mathrm{p}<70)$ & Medium \\
4 & $(40 \leq \mathrm{p}<55)$ & Low \\
\hline
\end{tabular}

After obtaining the self-efficacy value, then the independent sample $\mathrm{t}$-test was carried out, one of the assumptions of the independent sample $t$-test was the normality test and homogeneity test. If the data is normally distributed and homogeneous, then the parametric test is used, namely the independent sample t-test. Meanwhile, if the data is not normally distributed and not homogeneous, then a nonparametric test is used, namely the Mann Whitney test. The normality test used is Kolmogorov Smirnov, with the criteria if $p>0.05$, then the distribution is normal. Homogeneity test using Levene test, with criteria if $\mathrm{p}>$ 0.05 , then homogeneous. Data were analyzed using SPSS version 21 .

\section{Result and Discussion}

\section{Learning outcomes}

Data on the learning outcomes of the experimental class and the pretest and posttest control classes of students at MAN Banda Aceh can be seen in Table 3. 
Table 3. Independent Sample T-Test Test of Student Learning Outcomes

\begin{tabular}{lllll}
\hline Classes & $\begin{array}{l}\text { Average } \\
\text { Pretest }\end{array}$ & $\begin{array}{l}\text { Average } \\
\text { Posttest }\end{array}$ & t-count & $\begin{array}{l}\text { Independent } \\
\text { Sample T-test*) }\end{array}$ \\
\hline Experiment & 33.48 & 79.01 & 7.64 & $0.000<0.05$ \\
Control & 34.25 & 64.51 & & \\
* $^{*}=$ Independen Sampel T-test (Ha accepted,$\left.<0.05\right)$
\end{tabular}

The results showed that there were differences in student learning outcomes between the experimental class and the control class on environmental pollution material at MAN Banda Aceh. The learning outcomes of the experimental class increased significantly compared to the control class, this is because in learning that applies the Problem Base Learning model combined with the E-STEM-based Student Worksheet it provides an opportunity to identify problems related to environmental pollution and find solutions to overcome pollution problems water, air and land. Students make garbage nets to filter out the garbage in the gutters, and students design trash cans as trash bins, and design air purifiers that help in cleaning the air.

There is an effect of using the Problem Base Learning model on students' critical thinking skills, suggesting using the Problem Base Learning model in learning (Farisi, 2017). Learning the Problem Base Learning model makes students more understanding and interested. Students are more active in learning, so the application of the Problem Base Learning model can improve student learning outcomes (Fauzan, 2017).

The application of the Problem Base Learning model combined with the E-STEM-based Student Worksheet on the cognitive learning outcomes of students on the indicators of remembering, students are able to regain relevant knowledge from after learning about environmental pollution material. At the understanding stage, students are able to formulate the meaning of the learning message and are able to communicate it in written form by answering questions that are distributed about environmental pollution. At the application stage, students are able to apply based on the material that has been studied with practice questions so that students are trained to know what procedures will be used to solve problems.

At the implementing stage consists of cognitive processes which are the ability to remember and implement based on what has been learned during the learning process so that students are able to apply. At the analyzing stage, students are able to analyze to solve problems related to environmental pollution. At the assessment stage, students are able to make opinions and judgments based on problems by checking and considering situations, values or ideas which include the ability to make an opinion about something and be responsible for their opinion.

This result is also supported by the research of Tarhan and Burcin (2016), the Problem Base Learning model reflects that students' positive beliefs increase after each activity. Based on these results, it can be concluded that problem-based learning is effective in learning. The application of the Problem base learning learning model can improve student learning outcomes (Rerung., 2017).

\section{Self-Efficacy Results}

The data from the independent sample t-test posttest self-efficacy test results for the experimental class and the control class for pretest and posttest students at MAN Banda Aceh.

Table 4. Independent Sample T-Test Self Efficacy Test for Students

\begin{tabular}{lllll}
\hline Classes & $\begin{array}{l}\text { Average } \\
\text { Pretest }\end{array}$ & $\begin{array}{l}\text { Average } \\
\text { Posttest }\end{array}$ & t-count & $\begin{array}{l}\text { Independen } \\
\text { sampel t-testt*) }\end{array}$ \\
\hline Experiment & 35.12 & 83.58 & 7.09 & $0.000<0.05$ \\
Control & 35.74 & 72.48 & & \\
\hline
\end{tabular}

*) = Independen Sampel T-test (Ha accepted, < 0.05)

The results of the independent sample t-test were obtained $(\rho<0.001)$. There was a difference in students' self-efficacy between the experimental class and the control class on environmental pollution material at MAN Banda Aceh.

The average of each student's self-efficacy indicator with the application of the Problem Base Learning model combined with the E-STEM-based Student Worksheet on environmental pollution material in the experimental class is presented in Figure 1.

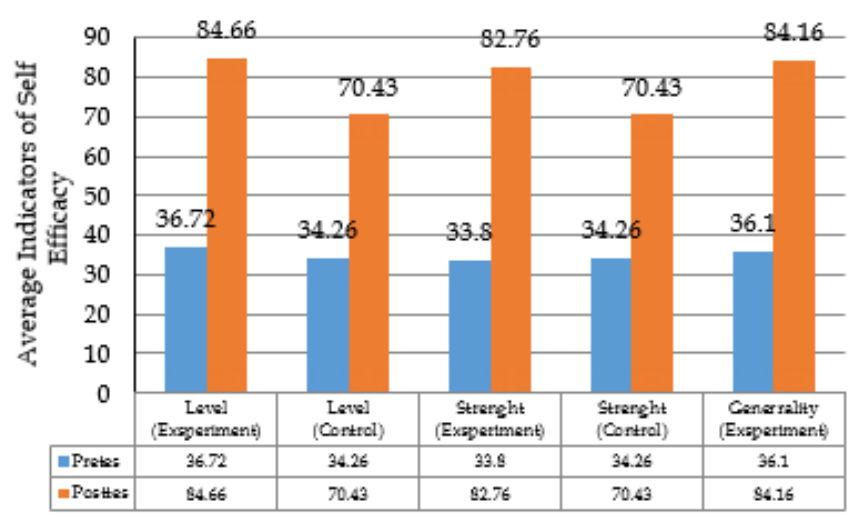

Figure 1. Average Self Efficacy Indicator of Students in Experiment Class and Control Class

Learning using the Problem Base Learning model combined with the E-STEM-based Student Worksheet is more effectively used to improve students' self-efficacy 
compared to the Problem Base Learning model on environmental pollution material at MAN Banda Aceh.

The average increase in self-efficacy indicators in the experimental class. The Problem Base Learning model is combined with the E-STEM-based Student Worksheet, helping students to develop problem solving skills and involve students in real or simulated experiences, and become autonomous and independent learners. During the learning process, it is the students who play a lot like a little scientist so that slowly they will build students' self-confidence so that they arouse curiosity more, be diligent in doing research and try hard so that the problems they face can be solved. Freedom carried out with groups will foster students' freedom in expressing their abilities so that this will further increase their independence and confidence in the learner's abilities. Students already understand the problem of base learning and are very enthusiastic about waiting for instructions from the teacher what to count, students are very focused and enthusiastic when given a real problem. It makes students have confidence and confidence to be able to solve the problems they face. This is in line with Islahul \& Utiya (2015) showing that self-efficacy has been successfully trained with a problem-based learning model with an increase in self-efficacy behavior.

Problem Base Learning group is better than conventional. Central to the effectiveness of Problem Base Learning is the ability of students to work in solving problems, so Problem Base Learning can be designed to facilitate student collaborative learning. The Problem Base Learning model can increase the selfefficacy of students in the high category (Masitoh, 2018).

Learning using Problem Base Learning is a learning strategy designed to improve learning by requiring students to study the subject matter while solving problems. The activities of students in overcoming problems in Problem Base Learning will make students improve their skills. Problem Base Learning uses problems as a context for students to acquire skills and knowledge, Problem Base Learning is student-centered, develops active learning, motivates learning (Anjai and Imoko, 2015).

At the time of the implementation of learning some students were responsive to the questions raised by the teacher and student learning outcomes also increased, but the increase that occurred was still less than the class that used the problem-based learning model. This is because problem-based learning patterns are learning with direction. In contrast to students who use project-based learning models, students who use problem-based learning models in problem-based learning classes are more interested in learning through self-directed learning so that they can improve learning skills (Goh, 2016).

\section{Conclusion}

There are differences in student learning outcomes after applying the Problem Base Learning model combined with E-STEM-based Student Worksheets on environmental pollution materials at MAN Banda Aceh. There are differences in students' self-efficacy after applying the Problem Base Learning model combined with the E-STEM-based Student Worksheet on environmental pollution materials at MAN Banda Aceh. The Problem Base Learning model appears when presenting problems in learning, students learn to explore knowledge through a process of repeated questions, active learning, sharing, and reflection. There is an interaction between the learning model and self-efficacy on student learning outcomes. Students must have high self-efficacy, so that they can support the success of the learning process and can increase student achievement. This is because selfefficacy has a strong influence on mathematical achievement. Students with high self-efficacy are able to solve problems than students with low self-efficacy.

\section{References}

Arends, R. (2013). Belajar Untuk Mengajar, Learning to Teach. Jakarta: Salemba Humanika. [Indonesian]

Apriyani, R., Ramalis, T. R., \& Suwarma, I. R. (2019). Analyzing Student's Problem Solving Abilities of Direct Current Electricity in STEM-based Learning. Journal of Science Learning, 2(3), 85-91. https:// doi.org/10.17509/jsl.v2i3.17559.

Amini, R., Setiawan, B., Fitria, Y., \& Ningsih, Y. (2019). The difference of students learning outcomes using the project-based learning and problembased learning model in terms of self-efficacy. Journal of Physics: Conference Series, 1387, 12082. https://doi.org/10.1088/1742$\underline{6596 / 1387 / 1 / 012082}$

Barrows, H. (2002). Is it Truly Possible to Have Such a Thing as dPBL? Distance Education, 23(1), 119122.

https://doi.org/10.1080/01587910220124026.

Chiang, C.-L., \& Lee, H. (2016). The Effect of ProjectBased Learning on Learning Motivation and Problem-Solving Ability of Vocational High School Students. International Journal of Information and Education Technology, 6, 709-712. https://doi.org/10.7763/IJIET.2016.V6.779. 
Hendriana, H., Johanto, T., \& Sumarmo, U. (2018). The role of problem-based learning to improve students' mathematical problem-solving ability and self confidence. Journal on Mathematics Education, 9(2), 291-299. https://doi.org/10.22342/jme.9.2.5394.291-300

Fast, L. A. (2015). Self-Efficacy and Standardized Test Performance. Physiological Research, 64(6), 897905

Fauzan, M., Abdul, G., \& Muhammad, S. (2017). Penerapan Model Problem Based Learning Pada Pembelajaran Materi Sistem Tata Surya untuk Meningkatkan Hasil Belajar Siswa. Jurnal Pendidikan Sains Indonesia, 5(1), 27-35. Retrieved from:

http://jurnal.unsyiah.ac.id/JPSI/article/view/8 $\underline{404}$ [Indonesian]

Farisi, A., Abdul, H., \& Melvina. (2017). Pengaruh Model Pembelajaran Problem Based Learning Terhadap Kemampuan Berpikir Kritis dalam Meningkatkan Hasil Belajar Siswa pada Konsep Suhu dan Kalor. Jurnal Ilmiah Mahasiswa (JIM) Pendidikan Fisika. 2(3): 283-287. Retrieved from: http://www.jim.unsyiah.ac.id/pendidikanfisika/article/view/4979 [Indonesian]

Goh, K. (2014). What good teachers do to promote effictive student learning in a problem-based learning environment. Australian Journal of Educational and Developmental Psychology, 14, 159166.

Güneş, P., Yildirim, O., \& Yılmaz, M. (2017). Development of the rubric self-efficacy scale. International Journal of Assessment Tools in Education, 5, 176-189. https://doi.org/10.21449/ijate.373040.

upta, R., LaMarca, N., Rank, S., \& Flinner, K. (2018). The Environment as a Pathway to Science Learning for K-12 Learners - A Case Study of the E-STEM Movement. Ecopsychology, 10. https://doi.org/10.1089/eco.2018.0047.

Hamalik, O. (2007). Proses Belajar Mengajar. Jakarta: Bumi Aksara. [Indonesian]

Islahul, N., \& Utiya, A. (2015). Implementasi Model Pembelajaran Berbasis Masalah (PBM) Untuk Melatihkan Keterampilan Berpikir Kritis dan Self Efficacy Pada Materi Pokok Faktor-Faktor Yang Mempengaruhi Laju Reaksi Kelas XI SMA Negeri 4 Sidoarjo. UNESA Journal of Chemical Education, 4 (1): 62-6 Retrieved from: https://jurnalmahasiswa.unesa.ac.id/index.php L... view/10781 [Indonesian]

Ajai, J., \& Imoko, B. (2014). Gender Differences in Mathematics Achievement and Retention Scores: A Case of Problem-Based Learning Method. International Journal of Research in Education and
Science,

1 ,

45.

https://doi.org/10.21890/ijres.76785

Karlina, D. M., Tenri Pada, A. U., Khairil, K., Artika, W., \& Abdullah, A. (2021). Efektivitas Modul Elektronik Berbasis Web Dipadu Problem Based Learning Terhadap Motivasi Belajar pada Materi Pencemaran Lingkungan. Jurnal Pendidikan Sains Indonesia, $9(1)$, 139-150. https://doi.org/10.24815/jpsi.v9i1.18135 [Indonesian]

Masitoh, L., \& Fitriyani, H. (2018). Improving students' mathematics self-efficacy through problem based learning. Malikussaleh Journal of Mathematics Learning (MJML), 1, 26. https://doi.org/10.29103/mjml.v1i1.679

NAAE. (2013). E-STEM: Linking Environmental Education with Science, Technology, Engineering and Math. North American association for environmental education \& underwriters laboratories.

Riduwan. (2009). Skala Pengukuran Variabel-Variabel Penelitian. Bandung: Alfabeta. [Indonesian]

Rerung, N., Iriwi, L.S.S., \& Widyaningsih, S.W. (2017). Penerapan Model Pembelajaran Problem Based Learning (PBL) untuk Meningkatkan Hasil Belajar Peserta Didik Sma Pada Materi Usaha Dan Energi. Jurnal Ilmiah Pendidikan Fisika AlBiRuNi, 6(1): 47-55. doi: https://doi.org/10.24042/jpifalbiruni.v6i1.597 [Indonesian]

Tarhan, L., \& Acar Sesen, B. (2013). Problem Based Learning In Acids And Bases: Learning Achievements And Students' Beliefs. Journal of Baltic Science Education, 12, 565-578. Retrieved from:

http://www.scientiasocialis.lt/ibse/?q=node/31 9.

Trianto. (2009). Mendesain Model-Model Pembelajaran Inovatif/Progresif. Jakarta: Predana Media Group. [Indonesian]

Tan, O.S. (2009). Problem Based Learning and Creativity. National Institute of Education,Nanyang Technological University, Singapore.

United States (2018). What is Environmental Education? USA: Environmental Protection Agency. Retrieved from: https://www.epa.gov/education

Utomo, T., Wahyuni, D., \& Hariyadi, S. (2014). Pengaruh Model Pembelajaran (Problem Based Learning) Terhadap Pemahaman Konsep dan Kemampuan Berfikir Kreatif Peserta didik. Jurnal Edukasi Unej, 1 (1):5-9. doi: https://doi.org/10.19184/jukasi.v1i1.1025

[Indonesian] 